\title{
Is the Revolution Over? Gender, Economic, and Professional Parity in Academic Library Leadership Positions
}

\author{
Marta Mestrovic Deyrup
}

This article examines recent statistics provided by the government and the library profession concerning gender, professional, and economic parity among academic library directors. The results revealed that women now hold the majority of library directorships and that women's economic compensation in some cases exceeds that of their male counterparts. The author conducted a two-part survey that looked at the gender of chief administrators at Carnegie doctoral/research extensive university libraries, these institutions' geographical location and funding mechanism, and the libraries' mission/vision statements and organizational hierarchies. Little difference was found between men and women in almost all areas examined. The findings of Hernon, Powell, and Young, which were published in the January 2002 issue of College \& Research Libraries, also were examined. The author asks whether the revolution is indeed over and what it might signify for the profession.

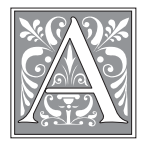

lthough women librarians have long been in the majority at academic libraries, they have recently risen to key leadership positions in the profession. ${ }^{1}$ At the most prestigious university libraries, the 124 Association of Research Library (ARL) institutions, ${ }^{2}$ women comprise 52.1 percent of all top administrators and serve as the majority on ARL's board of directors., ${ }^{3,4}$ These are impressive gains when one considers that in 1972 women accounted for only 4.6 percent of library directors at these research universities. ${ }^{5}$ Women also occupy the majority of positions on the executive board and officers' list of the ALA and the board of directors of the Association of College and Research Libraries (ACRL). ${ }^{6,7}$

Although these statistics are striking, women fare even better within the academic library community as a whole. According to statistics released in 1999 by the ALA's Office for Research and Statistics, women now constitute 57 percent of all college and university library directors. ${ }^{8}$ Perhaps more significant, women essentially have achieved wage parity with their male counterparts. The statistical difference in pay among all academic library directors is insignificant, with women earning approximately 92 percent of the average male salary, a fig-

Marta Mestrovic Deyrup is Assistant Professor/Librarian at Seton Hall University Library; e-mail: deyrupma@shu.edu. 
ure that is far better than the one for their counterparts at public libraries who earn approximately 14 percent less than male directors. And at the top-tier research institutions, women directors, on average, actually earn slightly more than men. ${ }^{9}$

These findings are supported by other recent studies that had as their focus gender and ethnic discrimination in library organizations. Elizabeth Jones and Charles Oppenheim, who focused on gender differences at libraries in the United Kingdom, observed that inequities in salary and rank were not due primarily to a "glass ceiling." Rather, they were the result of women assuming the dual role of caretaker and wage earner. This caused them to leave and then reenter the workforce, precipitating a drop in pay and professional status. ${ }^{10}$ Deborah R. Hollis, who presented a convincing case that an "old girl network" has emerged at academic libraries, noted that women as a group - but not women of color - made "substantial gains" in breaking into academic library management in the 1980s and 1990s and now hold key leadership positions at National Collegiate Athletic Association institutions. ${ }^{11}$

If parity has been achieved, a number of questions have to be asked. How do academic librarians compare with their counterparts in the private and public sectors? What led to the shift in leadership within academic librarianship? Has the organizational culture of academic libraries changed to reflect a feminist or "women-centered" agenda? And, perhaps most important, should the success the profession has had in the past in achieving economic and professional parity serve as a model for the future?

\section{Wage and Professional Parity: A Comparison with the Business and Educational Communities}

In many ways, academic librarianship is a hybrid profession. At the highest levels, it is similar in practice to business administration. Library managers, after all, are responsible for a host of client-centered services that are driven by technology - just as in the private sector. They administer budgets, meet a payroll, supervise building construction and maintenance, and so forth. However, the career trajectory of academic librarians who move into administrative positions is more like that of faculty who are promoted to department heads and later deans. This ambivalence is seen in the job skills needed to become an academic library administrator, which are largely managerial, and in the educational degree most valued for advancement - the doctorate.

Whereas the library profession as a whole is underpaid, female academic library managers have made gains that have not been equaled by their professional counterparts in business and higher education administration. Female academic library administrators have had far more success percentagewise in reaching the upper levels of the workforce than their colleagues in the corporate environment. In its 2000 findings, the nonprofit organization Catalyst reported that high-achieving women had made only marginal gains in the business world from the previous year:

In 2000, women represented 12.5 percent of the corporate officers among all Fortune 500 companies (as of March 31, 2000), compared to 11.9 percent in 1999 . The same year, there were 83 companies with women corporate officers who are top earners, compared to 1999's total of 72. This amounts to 16.6 percent of Fortune 500 companies, in contrast to 14.4 percent in 1999. In addition, women top earners represented 4.1 percent of all top earners in 2000, compared to 3.3 in 1999. In 2000, 48.9 
percent of all corporate officers had line responsibility.... Of all line officer jobs in 2000, 92.7 percent were held by men, while women filled the remaining 7.3 percent - up from 6.8 percent in $1999 .{ }^{12}$

Women library directors also have surpassed most female faculty and administrators in the higher education community in the percentage of leadership positions they occupy and at the uppermost level in terms of economic parity with their male colleagues. In her analysis of gender differences among university administrative and faculty positions, Karen Dugger noted that the overall increase of women in leadership positions in the higher education community remained relatively small during the period between the mid-1970s and late 1990s. Most of their gains were in smaller institutions, she said. In addition, Dugger claimed that women have not made gains in terms of job parity within the teaching profession, occupying mostly positions at the instructor or lecturer level and only 19 percent of full professor slots:

From 1975 to 1998 the percentage of women presidents has risen substantially from 5 to $19 \%$. However, the great majority of women presidents are concentrated in small colleges and universities with enrolments of less than 3,000. Although women now hold a greater proportion of presidential positions, they remain under-represented compared to their share of all faculty and senior staff positions at US colleges and universities (40 percent)... . Women now constitute one-third of the faculty of institutions of higher education in the United States.... The percentage of full professors who are women, however, continues to be low at $19 \%$. At the assistant professor rank, women are reaching parity with men. Women continue, however, to be over-represented at the level of instructor or lecturer. ${ }^{13}$

The one area in which there appears to be a similarity between the higher education teaching profession and academic library administration is in terms of overall economic compensation. As noted earlier, for all higher education there is an eight percent gap between the salaries of female and male academic library directors, which is in keeping with "an average disparity of eight percent between male and female salaries" in the higher education teaching profession. ${ }^{14}$ However, these numbers obscure the fact that women library directors at the top institutions are generally much better compensated. According to ARL statistics, the average salary for fiscal year 2000-2001 for library directors within the organization amounted to $\$ 136,216$, which more than equaled the average salaries of the upper level of the higher educational community at large..$^{15}$ And it must be remembered that the majority of these ARL directors are now women.

Although it is common for the library profession to focus on a perceived marginalization of libraries and librarianship within the academic community, the fact remains that university and college libraries and the women who lead them are accountable for very significant fiscal and personnel resources. According to 1998 statistics issued by the Department of Education, expenditures for libraries at degree-granting postsecondary institutions amounted to $\$ 4.6$ billion. The total FTE library staff at academic libraries numbered 96,709. ${ }^{16}$ ACRL statistics, released three years later, point to a mean of 124 for FTE library staff for doctoral-granting institutions and sixteen for bachelor of arts colleges. ${ }^{17}$ These statistics can be put into perspective if one looks at the expen- 
ditures of four of the larger public and private libraries: Georgetown, $\$ 18,650,515$; Indiana University at Bloomington, $\$ 26,459,375$; MIT, $\$ 12,024,841$; and North Carolina State University at Raleigh, $\$ 19,165,070 .{ }^{18}$ All are run by women.

In light of this fact, it might be instructive to take a look at the careers of these women. For the most part, they constitute the same generation. What were the forces that shaped their careers and led to their professional success?

\section{The Shift in Leadership: A Feminist Perspective}

In its 2002 white paper, the ACRL Adhoc Task Force on Recruitment and Retention Issues noted that more than 60 percent of ARL librarians were due to retire in the next decade. ${ }^{19}$ The ARL statistics are mirrored by those of the profession at large, which point to a massive retirement of current women librarians over the next twenty years. These statistics, though sobering, point to a generation of leaders who began and will finish their careers as a cohort.

Unlike their predecessors, these female academic library directors - now in their fifties and sixties - directly benefited from the feminist movement. They were part of the first generation of women to reap the rewards from implementation of Title IX in 1972. This federal regulation prohibited discrimination in higher education and made it possible for women who worked within academic librarianship to be promoted and gain leadership status.

In 1985, Barbara B. Moran presented a comprehensive look at the impact of affirmative action on the profession during the 1970s and 1980s. ${ }^{20}$ Although it may seem almost improbable now to a younger generation, academic librarians during these two decades were involved in enormous struggles for equality. Moran cited three class-action suits involving what are today Carnegie doctoral research/exten- sive universities, one of which resulted in thirty-seven women librarians being awarded \$900,000 in compensation. ${ }^{21}$ Although the gains these librarians made appear slight from the vantage point of when the article was written, they mark the beginning of a sea change in both economic and professional parity between female and male library managers. The number of women library directors at the top research libraries more than doubled between 1982 and 1997 from 22.4 to 45.2 percent, and as the statistics have shown, women now dominate leadership positions in academic libraries. ${ }^{22}$

Janice J. Kirkland made an excellent argument that these women were able to achieve directorships through a combination of networking and academic and professional credentials. In 1997, she conducted a survey of 135 women academic library directors that focused on women administrators' perceived reasons for advancement. When asked to rank the factors for their success, the study participants cited the following in order of importance: professional organizations, academic majors/degrees, tenacity/perseverance, mobility, and mentors. ${ }^{23}$ However, Kirkland also noted that the single most significant factor was mentoring, an aspect that Betty J. Turock has commented on as well. ${ }^{24,25}$

A case can be made that the structure of library professional associations with their myriad divisions, sections, and committees and that the fluidity with which members are able to rise to leadership positions were of great benefit to women, who in earlier generations were unable to progress within their own institutions. The same can be said about the ALA's decision to advocate positions that benefited its disenfranchised majority.

These women took part in an enormous paradigm shift within the profession. Turock viewed these changes through a feminist perspective. She described four 
stages in the development of women leadership roles throughout history. The last three phases roughly correspond to the changes that occurred within the academic library profession over the past thirty years. According to Turcock, this development consists of:

Phase I. Womanless Leadership, in which women are invisible, leadership is exclusively the province of men, and only a few exceptional women become part of history

\section{Phase II. Women as a Leadership Anomaly, in which women are perceived as having problems that must be corrected to enter the ranks of effective leaders}

Phase III. Women as Leaders, in which women take the initiative to propose new views of leadership and to lead in ways that arise from a different base of assumptions

Phase IV. Leadership Redefined, in which reconstruction leads to the inclusion of all leadership patterns crucial for future success ${ }^{26}$

Turock relied on Sally Helgesen, the theorist who "conceptualized an organizational structure in which leaders were at the center of an interconnected web, rather than the traditional organizational chart which placed the leader at the top ... of the organization." ${ }^{27}$ Although believing that “old culture hierarchical structures"28 still

\begin{tabular}{|l|c|c|}
\hline \multicolumn{3}{|c|}{$\begin{array}{c}\text { TABLE 1 } \\
\text { Total Number of Library Chief } \\
\text { Administrators }\end{array}$} \\
\hline \hline Gender & Number & Percent \\
\hline Male & 68 & 45 \\
\hline Female & 83 & 55 \\
\hline Total & $\mathbf{1 5 1}$ & $\mathbf{1 0 0}$ \\
\hline
\end{tabular}

remain, Turock posited that "the library can become, if it is not already, the model for the parent organization." 29

Turock's view of a radically altered library culture is supported by Paula T. Kaufman, who believes a women-centered management style now is emerging within the library profession:

Society is being transformed from the dominator to the partnership model, and to a values-based model. Organizational cultures are also being transformed to a gentler, or in terms of stereotypes, to a more "feminine" style of leadership. Some authors suggest that the nurturing management behavior shown by new library directors, regardless of gender, suggest that women are influencing and changing the library workplace rather than adopting the stereotypical male role model..$^{30}$

These four writers have taken as their themes cornerstones of this generation's experience in the workplace-affirmative action; advancement through a process of mentoring and professional affiliation; and the recognition by women administrators that they have different leadership styles than men and can use this understanding to their advantage.

It is paradoxical that although these experiences will probably all strike a chord with today's cohort of women academic library administrators, the last is probably not a factor in these women's success. This survey of academic library administrators at Carnegie doctoral research/extensive institutions and an earlier survey of ARL library directors ${ }^{31}$ point, instead, to behavioral uniformity within the managerial culture. They suggest that women's leadership styles are not fundamentally different from those of men. Rather, leadership style is deter- 


\begin{tabular}{|l|c|c|c|c|}
\hline \multicolumn{5}{|c|}{ TABLE 2 } \\
Institutional Funding and Gender \\
Representation \\
\hline \hline \multirow{2}{|c|}{} & \multicolumn{3}{c|}{ Gender } & \\
\cline { 3 - 5 } \multicolumn{2}{|c|}{} & Male & Female & Total \\
\hline Funding & Public & 45 & 57 & 102 \\
\hline & Private & 23 & 26 & 49 \\
\hline Total & & $\mathbf{6 8}$ & $\mathbf{8 3}$ & $\mathbf{1 5 1}$ \\
\hline
\end{tabular}

mined by educational culture and by the practical considerations of running multimillion-dollar academic support units. Affirmative action, rather than creating a new kind of gender-specific management, has resulted in the opposite-women assuming mainstream leadership roles.

\section{Women in Leadership Positions: A Traditional Model?}

A survey was conducted of Carnegie doctoral research/extensive institutional libraries. ${ }^{32}$ These 151 libraries were selected because they provided a manageable survey pool and are representative of top-tier public and private institutions. The survey was designed to elicit information about the gender of the libraries' top administrator and their organizational structure and mission/vision statement. Between December 2002 and January 2003, a search was done of each university's Web site to determine the title, name, and gender of the chief library administrator. The Web sites were revisited seven months later. If a mission statement or organizational chart were posted, it was examined to see whether the directors had embraced a nontraditional or a traditional model of management.

A statistical breakdown of these institutions was done by gender, funding method, and geographical location. The findings were in keeping with previous surveys and pointed to the dominance of women in leadership positions. ${ }^{33,34}$
Within the universe of the 151 academic library institutions examined, approximately 45 percent were headed by men and 55 percent by women. (See table 1.) Women administrators were in the clear majority in the Northeast and somewhat in the majority in the Midwest and Northwest. They comprised the majority of top library administrators at public institutions. The percentage of women administrators was virtually the same as that of men at private institutions. (See table 2.) When a second survey was done to identify those libraries that had clearly defined mission statements or organizational charts, the results showed the following: Of the 151 libraries surveyed, approximately 20 percent had traditional organizational charts clearly posted as a link from their home page and 48 percent provided the job responsibilities of staff that appeared to follow a traditional (i.e., generally hierarchical) structure. Approximately four percent of the libraries appeared to follow a team model of organization. (See table 3.) Thirty-three percent of these libraries posted mission/vision statements. (See table 4.) Most were posted separately, although some were contained within the general information provided on the library page. The majority emphasized service, access, technology, instruction, collection development, and library-faculty partnerships, all goals that were in keeping with the libraries' positions as support units within the university. Fourteen percent expressed a commitment

\begin{tabular}{|c|c|c|c|c|}
\hline \multicolumn{5}{|c|}{$\begin{array}{c}\text { TABLE } 3 \\
\text { Organizational Chart and Gender } \\
\text { Representation }\end{array}$} \\
\hline & & \multicolumn{2}{|c|}{ Gender } & \multirow[b]{2}{*}{ Total } \\
\hline & & Male & Female & \\
\hline Org. chart & yes & 11 & 19 & 30 \\
\hline Org. chart & no & 20 & 22 & 42 \\
\hline Hier. model & yes & 34 & 39 & 73 \\
\hline Team model & yes & 3 & 3 & 6 \\
\hline \multicolumn{2}{|l|}{ Total } & 68 & 83 & 151 \\
\hline
\end{tabular}




\begin{tabular}{|c|c|c|c|c|}
\hline \multicolumn{5}{|c|}{$\begin{array}{c}\text { TABLE } 4 \\
\text { Mission Statement and Gender } \\
\text { Representation }\end{array}$} \\
\hline & & \multicolumn{2}{|c|}{ Gender } & \multirow{3}{*}{\begin{tabular}{|c|} 
Total \\
49
\end{tabular}} \\
\hline & & Male & Female & \\
\hline \multirow[t]{2}{*}{ Mission } & yes & 20 & 29 & \\
\hline & no & 48 & 54 & 102 \\
\hline Total & & 68 & 83 & 151 \\
\hline
\end{tabular}

to diversity among their staff. Perhaps not surprising, women were more likely than men (three to one) to post information in their mission/vision statements that appeared to display women-centered values, emphasizing qualities such as the nurturing of employees, flexibility, creativity, and so forth. However, taken statistically, this amounted to only eight percent of online postings. Women also were approximately 26 percent more likely to post traditional hierarchical organizational charts than their male counterparts-a result that was somewhat surprising.

In a two-part article that appeared in 2001 and 2002 in College \& Research Libraries, Peter Hernon, Ronald R. Powell, and Arthur P. Young asked: "What are the currently desirable attributes [of leadership] and which ones will be important in the next decade?"35 Conspicuously absent from their study of ARL institutions was a discussion of gender. The fact that this was not brought up by the participants whom they surveyed was equally revealing. Both directors and likely future directors responded in a very similar fashion, giving high rankings to traditional leadership values such as a commitment to service, political savvy, organizational ability, and priority-setting. Future ARL directors were more likely to emphasize the values of team-building and interpersonal skills, perhaps an indication that Turock's and Kaufman's predictions were correct. However, as the survey above and Hernon, Powell, and Young's article reveal, the over- all impression of library administrators is of conservatism, in terms of both a managerial culture and leadership values.

\section{Whither the Profession?}

Women now in their twenties and thirties - the age at which a new cohort of women enters academic librarianship-are in a very different position than their predecessors were at the start of their careers. They are joining a field in which women already dominate leadership positions. If they reach the top of the profession, they stand to have a great deal of professional responsibility and be financially well compensated. These women are the true inheritors of the policies of affirmative action. Yet, the education they receive in graduate school probably will not prepare them for a managerial career.

The U.S. News Report ranked the University of North Carolina, Chapel Hill; the University of Illinois at Urbana-Champaign; the University of Pittsburgh; and the University of Michigan as four of the top library schools in the country. ${ }^{36}$ Each has a predominance of women enrolled or enrolling in their graduate programs of library or information science. ${ }^{37}$ Although many of these schools have restructured their programs to include a stronger emphasis on information technology, none has chosen to focus on an academic or public library management curriculum. The University of North Carolina offers a dual MSIS/MBA degree, the University of Illinois at Urbana-Champaign offers management and consulting for the information services track, and the University of Michigan offers a specialization for information economics, management, and policy, but a glance at these schools' curricula does not show an emphasis on library management.

Although traditional library programs have helped create exceptional leadership opportunities for women, the time might be ripe to ask whether this should be the 
only direction offered for professional training. Academic librarianship, particularly at the top levels, is a managerial profession. As mentioned earlier in this study, these directors control yearly budgets that total more than four billion dollars. They handle client-centered transactions numbering in the millions. To suggest, as the literature cited in this article has done, that the current path of advancement-mentorship, on-the-job training, and professional affiliation -is sufficient is to ignore the very real benefits that could derive from training on the order of that received in professional schools of management and business.

\section{Conclusion}

Is the revolution over? In her seminal study, Moran noted that women academic librarians first were promoted at Liberal Arts I Colleges before breaking into the ranks of management at other institutions. ${ }^{38}$ This echoes the situation of women academic deans today. These women are just now making the transition from being heads of liberal arts colleges and the traditionally female-dominated schools of nursing and education to becoming heads of other academic schools and colleges. ${ }^{39}$ It might prove useful for this generation of academic administrators to take a look at what their colleagues within the library profession already have achieved.

This report has sought to show the real achievements the academic library profession has made in terms of gender equality. It is a model by which other professions in which women are-or can become-the majority should judge themselves. This is hinted at, if never explicitly developed, in the feminist literature. Historically, gender equality was the result of the profession's continuing emphasis on the overriding humanistic values that are central to librarianship and affirmative action and Title IX, which created a level playing field for women. These values have served the profession well. But although the issue of women's advancement to parity in the academic library field has reached a satisfactory resolution, two new ones-retention and recruitment-have arisen as the breakthrough generation of women library managers reaches retirement. With the retirement of many of these women from the profession, a successor study could focus on a model for new recruitment efforts for bringing women-and men-into the profession with the goal of becoming professional managers. The profession might choose to team up with business teaching faculty to provide training and recruitment of new postdoctoral students who wish to stay in the academy but are discouraged by job prospects or to target an entirely undergraduate population that seeks to enter a managerial career. It could identify those individuals currently in library school who are ambitious and wish for administrative positions - the way male library students were encouraged in the past to pursue this goal. It would be ironic that just as women have begun to achieve real parity in the profession, their gains were eroded by the lack of an ability to attract new members to the field.

\section{Notes}

1. According to 1999 statistics on gender and salary differences among library directors released by ALA Office for Research Statistics. Available from http://www.ala.org/hrdr/1999_report.html.

2. A list of member libraries is provided at the ALA site. Available from http://www.arl. org/members.html.

3. James G. Neal, “Turnover Trends of ARL Library Directors 1948-2002,” Oct. 16, 2002. Power point presentation of ARL presentation is available from http://www.arl.org/arl/proceedings/141/neal_files/frame.htm.

4. A list of ARL board members is available from http://www.arl.org/arl/board03.html. 
5. Neal, "Turnover Trends of ARL Library Directors 1948-2002."

6. ALA's list of officers and board members for the current year is available from http://www. ala.org/ala/ourassociation/governanceb/executiveboard/executiveboardroster.htm.

7. ACRL's list of board of directors is available from http://www.ala.org/ala/acrl/aboutacrl/ acrlboard/boardroster.htm.

8. ALA Office for Research Statistics on Gender and Salary Differences among Library Directors.

9. According to the ARL annual salary survey for the FY 2000-2001, male library directors, on average, earn $\$ 133,007$ and women library directors earn $\$ 136,216$. Available from http://www. arl.org/stats/salary/2000-01/t17.html.

10. Elizabeth Jones and Charles Oppenheim, "Glass Ceiling Issues in the UK Library Profession," Journal of Librarianship and Information Science 34, no. 2 (June 2002): 114.

11. Deborah R. Hollis, "Affirmative Action or Increased Competition: A Look at Women Minority Deans," Journal of Library Administration 27, no.1-2 (1999): 70.

12. Catalyst has released its 2000 census of women corporate officers and top earners in an online format, available at http://www.catalystwomen.org/research/censuses.htm\#2001wbd.

13. Karen Dugger, "Women in Higher Education in the United States," International Journal of Sociology and Social Policy 21, no. 1-2 (2001): 132.

14. Ibid., 133.

15. ARL annual salary survey for FY 2000-2001.

16. These figures are derived from 1998 information released by the National Center for Education Statistics, available from http://nces.ed.gov/surveys/libraries/highlights.asp\#academic.

17. According to 2001 ACRL data tables, available from http://www.virginia.edu/surveys/ ACRL/2001/sdp4.pdf.

18. These figures were calculated using the National Center for Education Statistics Academic Library Peer Comparison Tool for FY2000, available at http://nces.ed.gov/surveys/libraries/academicpeer/varlist.asp.

19. The ACRL Adhoc task force study on recruitment and retention issues is available to ACRL members only from http://www.ala.org/ala/acrl/acrlissues/acrlrecruiting/recruitingprofession.htm under the heading "Recruitment, Retention \& Restructuring: Human Resources in Academic Libraries."

20. Barbara B. Moran, "The Impact of Affirmative Action on Academic Libraries," Library Trends 34 (fall 1985): 199-217.

21. Ibid., 203.

22. Neal, "Turnover Trends ARL Library Directors 1948-2002."

23. Janice J. Kirkland, "The Missing Women Library Directors: Deprivation versus Mentoring," College \& Research Libraries 58 (July 1997): 381-82.

24. Ibid., 382.

25. Betty J. Turock, "Women and Leadership," Journal of Library Administration 32, no. 3-4 (2001): 120 .

26. Ibid., 114.

27. Ibid., 123.

28. Ibid., 127.

29. Ibid., 126.

30. Paula T. Kaufman, “Library Leadership: Does Gender Make a Difference?” Journal of Library Administration 18, no. 3-4 (1993): 122.

31. Peter Hernon, Ronald R. Powell, and Arthur P. Young, "University Library Directors in the Association of Research Libraries: The Next Generation, Part II," College \& Research Libraries 63, no. 1 (Jan. 2002): 73.

32. Available from http://www.carnegiefoundation.org/Classification/CIHE2000/PartIfiles/ DRU-EXT.htm. The Carnegie Foundation classifies doctoral research/extensive universities as "typically [offering] a wide range of baccalaureate programs, and ... committed to graduate education through the doctorate. During the period studied, they awarded 50 or more doctoral degrees per year across at least 15 disciplines."

33. Hollis, "Affirmative Action or Increased Competition: A Look at Women Minority Deans," 70.

34. Available from http://www.ala.org/hrdr/1999_report.html.

35. Hernon, Powell, and Young, "University Library Directors in the Association of Research Libraries: The Next Generation, Part II," 73.

36. Information about the U.S. News Report 1999 rankings for library schools is available from http://www.usnews.com/usnews/edu/grad/rankings/lib/brief/infos_brief.php.

37. An e-mail query was sent to each of the schools (July 2003) to find out the percentage of students enrolling in library school of either sex.

38. Moran, "The Impact of Affirmative Action on Academic Libraries," 211.

39. Mimi Wolverton and Mary Jo Gonzales, "Career Paths of Academic Deans." Paper presented at the annual meeting of the American Research Association in New Orleans (Apr. 24-28, 2000): 6. 